\title{
Mediators and Mechanisms of Pancreatic Beta-cell Death in Type 1 Diabetes
}

\section{perspectiva}

\author{
PIERRE PIROT \\ Alessandra K. Cardozo \\ DÉCIO L. EIZIRIK
}

Laboratory of Experimental Medicine, Université Libre de Bruxelles (ULB), Brussels, Belgium

\begin{abstract}
Type 1 diabetes mellitus (T1D) is characterized by severe insulin deficiency resulting from chronic and progressive destruction of pancreatic beta-cells by the immune system. The triggering of autoimmunity against the beta-cells is probably caused by environmental agent(s) acting in the context of a predisposing genetic background. Once activated, the immune cells invade the islets and mediate their deleterious effects on beta-cells via mechanisms such as Fas/FasL, perforin/granzyme, reactive oxygen and nitrogen species and pro-inflammatory cytokines. Binding of cytokines to their receptors on the beta-cells activates MAP-kinases and the transcription factors STAT- 1 and $\mathrm{NF} \kappa-\mathrm{B}$, provoking functional impairment, endoplasmic reticulum stress and ultimately apoptosis. This review discusses the potential mediators and mechanisms leading to beta-cell destruction in T1D. (Arq Bras Endocrinol Metab 2008;52/2:156-165)
\end{abstract}

Keywords: Pancreatic beta-cell; Diabetes mellitus; Apoptosis; Cytokines; Endoplasmic Reticulum; ER stress

\section{RESUMO}

Mecanismos de Destruição e Morte da Célula-beta Pancreática no Diabetes. O diabetes melito tipo 1 (DM1) tem como característica uma grave deficiência de insulina que resulta da destruição da célula-beta, crônica e progressiva, pelo sistema imune. $O$ desencadeamento da autoimunidade contra a célulabeta é causado, provavelmente, por agentes ambientais que atuam quando existe predisposição genética. Uma vez ativadas, células imunes invadem as ilhotas, e os efeitos deletérios sobre as células-beta são mediados por mecanismos relacionados a Fas/FasL, perforina/granzima, espécies reativas de oxigênio e nitrogênio, e a citocinas pró-inflamatórias. A ligação de citocinas a seus receptores na célula-beta ativa MAP-quinase e fatores de transcrição STAT-1 e NFkB, provocando prejuízo funcional, estresse de retículo endoplasmático e, por fim, apoptose. Esta revisão discute os mecanismos e os mediadores potenciais que levam à destruição da célula-beta no DM1. (Arq Bras Endocrinol Metab 2008;52/2:156-165)

Descritores: Célula-beta pancreática; Diabetes melito; Apoptose; Citocinas; Estresse do retículo endoplasmático

\section{THE GENETIC BACKGROUND OF} TYPE 1 DIABETES MELLITUS (T1D)

Recebido em 19/1 1/2007 Aceito em 03/12/2007
YPE 1 Diabetes MELLITUS (TID) accounts for about $10-15 \%$ of all cases of
diabetes (1). TID is a multifactorial disease where a genetic predisposi- 
tion combines with environmental trigger(s) to induce the activation of a specific autoimmune destruction of pancreatic beta-cells (1-3).

Several loci, increasing the risk to develop T1D, have been identified (2-5). Among them, the human leukocyte antigen (HLA) locus is by far the most common predisposing polymorphism $(2,4)$. Other well documented predisposing loci include the insulin locus, the cytotoxic T-lymphocyte antigen 4 (CTLA4) locus and the phosphatase non-receptor type 22 (PTPN22) locus $(2,3)$. In addition, a recent genome wide association study of 2000 TID subjects suggested several new candidate loci, encoding for genes involved in immune signaling, such as the receptor tyrosine kinase ErbB3 (ERBB3), the SH2B adaptor protein 3 (SH2B3/ LNK), the TRAF-type zinc finger domain containing 1 (TRAFDl) and the protein tyrosine phosphatase nonreceptor type 11 (PTPNII) $(4,5)$. Most of these genes are related to the immune system, and may predispose the individual to an exacerbated inflammatory and immune response to a given stimulus, potentially increasing the risk of autoimmunity. Others, such as the insulin locus and some tyrosine phosphatases, may affect beta-cell function and antigen presentation.

The HLA locus contains genes coding for the major histocompatibility complex (MHC) molecules (6). There are two types of MHC molecules: 1) MHC class I - which are expressed in almost every nucleated cell of the body and are involved in the presentation of intracellular antigens; 2) MHC class II - which are expressed at the surface of antigen presenting cells (APC) (i.e. dendritic cells, macrophages and lymphocytes-B) and involved in the presentation of extracellular antigens. MHC class II are present in three different forms: DR, DQ and DP which are composed of two chains ( $\alpha$ and $\beta$ ) encoded by genes $A$ and $B$. The genetic predisposition to TID caused by the HLA locus is related to specific polymorphisms of the DQ and DR forms of the MHC class II molecules (1-3). Some specific combinations of alleles for the DQAl and $\mathrm{DQBl}$ genes, namely DQA1 *0501-DQBI *0201, DQAl *0301-DQBI *0302 and alleles for the DRBI gene namely $\mathrm{DRBI}{ }^{*} 03$ and $\mathrm{DRB1}{ }^{*} 04$, significantly increase the risk to develop T1D. Homozygosity for either of these risk haplotypes is identified in $30 \%$ of TID patients but only in $3 \%$ of the general population (3). On the other hand, the haplotype $\mathrm{DQAl}{ }^{*} 0102-\mathrm{DQBI}{ }^{*} 0602$ is protective against TID. The effect of the HLA locus on TID risk is probably due to a non-optimal presentation of self-anti- gens to naïve lymphocytes during their maturation process in the thymus, leading to an inefficient deletion of auto-reactive lymphocytes. In line with this, transgenic expression of the MHC class II risk allele in mice sensitizes the immune system to beta-cell autoantigens, such as glutamic acid decarboxylase (GAD65) (7). The polymorphisms of the insulin locus that increase diabetes risk are characterized by variable numbers of tandem repeat (VNTR) regions $\sim 365$ bp upstream of the translational start site (3). The number of VNTRs (from 30 to 170 repeats) affects the level of expression of the insulin gene; low amounts of VNTRs (30 to 60 repeats) cause high expression in the pancreas and low expression in the thymus. Low expression of insulin in the thymus may lead to inefficient destruction of selfreactive T-cells during their maturation process (3). The other predisposition loci, PTPN22 and CTLA4, encode for negative regulators of lymphocyte activity. The PTPN22 locus encodes Lyp, a tyrosine phosphatase that inhibits antigen-specific T-cell activation by dephosphorylating key components of the T-cell receptor (TCR) signaling cascade (3). CTLA4 is a T-lymphocyte receptor which interacts with a ligand expressed at the surface of B-lymphocytes and dendritic cells, causing inhibition of T-lymphocyte activation (3). The polymorphisms for those loci associated with TID are characterized by a loss of function leading to hyperactivity of T-lymphocytes.

\section{ONSET OF T1D: ENVIRONMENTAL TRIGGERS, RECRUITMENT AND ACTIVATION OF IMIMUNE CELLS}

The earliest sign of autoimmunity against beta-cells, often detectable months or years before the appearance of clinical symptoms, is the presence of circulating antibodies against beta-cell antigens (8). These antibodies are used as markers of diabetes risk (2). The most common auto-antibodies in pre-diabetic patients are directed against glutamic acid decarboxylase (GAD65), tyrosine phosphatase-like protein (IA-2) and insulin (IAA). Up to $90 \%$ of newly diagnosed TID subjects have autoantibodies to one or more of these antigens (8), and autoimmunity detection rates raise to $98 \%$ when combining the detection of these antibodies with detection of antibodies against the newly discovered beta-cell autoantigen ZnT8 (9). Epidemiological studies have shown that antibodies against beta-cell antigens can appear after a few months/years of life, 
suggesting that the autoimmune process is triggered early in life $(2,8)$. This indicates that the pool of selfreactive naïve T-cells stays under the control of the immune system for several years, with many antibody positive individuals never developing insulitis nor diabetes (10). External events may therefore be required for the activation and expansion of the auto-reactive naïve T-cells. Suspected environmental triggers include viral infection, dietary factors during infancy (e.g. cow milk), vaccination, toxins and the physiological betacell turnover occurring in the newborn $(11,12)$. Accumulating evidence points to viral infections by enterovirus, rubella, mumps, rotavirus, parvovirus or cytomegalovirus as the most probable candidates for triggering beta-cell autoimmunity (13). Particular attention is given to the enteroviruses which have a specific tropism for the pancreas (13). Epidemiological studies investigating the seasonal appearance of betacell autoantibodies in a group of risk individuals showed preferential emergence of the self-antibodies during the cold season, correlating with a period of increased enterovirus infections (11). Enterovirus of the coxsakie family, isolated from diabetic patients, were able to induce diabetes when injected into susceptible mice (13). More recently, a coxsackie B4 virus was isolated from three out of six samples obtained from TID patients. This virus was able to infect human islets from non-diabetic patients in vitro, causing impaired glucose stimulated insulin release (14).

The process by which enteroviruses activate autoreactive T-lymphocytes remain elusive, but possible mechanisms include release of beta-cell antigens via non-T-cell mediated beta-cell cytolysis, expression of viral antigens at the surface of the beta-cells (thus breaking the self tolerance) and activation of self-reactive T-lymphocytes due to molecular mimicry between viral proteins and beta-cell antigens (13). Once activated, the autoreactive T-lymphocytes must be recruited to the pancreatic islets to cause diseases. The initiator events of islet inflammation process, i.e. insulitis, remain to be elucidated; this is, at least in part, secondary to the scarcity of human pancreatic samples available for research, and the fact that this material is usually obtained via autopsy or pancreatic biopsy (an ethically debatable practice) of patients with established TID, when most beta-cells have already been destroyed $(15,16)$. Thus, most of our present knowledge of the early pathogenesis of TID is based on observations in animal models of TID, such as the non-obese diabetic (NOD) mice, the BioBreeding
(BB) rat (17) and the more recently established LEW.IARl/Ztm-iddm rat (18).

The process of T-cell recruitment to the pancreatic islets is not fully understood but it may involve local production of chemokines by specialized APCs, such as the resident dendritic cells (DC) and macrophages, endothelial cells and the beta-cells themselves (19) (Figure $1 \mathrm{~A}, \mathrm{C}, \mathrm{D})$. Chemokines belong to the cytokine family. They are a group of low molecular weight peptides which recruit, activate and co-stimulate cells of the immune system (19). The cytokines TNF- $\alpha$ and IFN- $\gamma$ induce the release of chemokines by resident macrophages and endothelial cells (19). Transgenic expression of the chemokine macrophage chemoattractant protein-l (MCP-1; also called CCL2) under the control of the rat insulin promoter induces monocyte infiltration in pancreatic islets (20), while NOD mice deficient for the macrophage inflammatory protein-l $\alpha$ $(\mathrm{MIP}-\mathrm{l} \alpha)$ has reduced destructive insulitis and are protected against diabetes (2l). Transgenic RIP-GP mouse (a virus-triggered diabetes mouse model) deleted for CXC3R, the receptor for the IFN- $\gamma$-induced chemokines Mig, IP10 and I-TAC have decreased the incidence of diabetes upon infection with lymphocyte chroriomeningitidis virus (LCMV) (19). The beta-cells themselves secrete chemokines following viral infection or exposure to cytokines. Exposure of rat beta-cells to IFN- $\gamma$ in combination with double stranded RNA (a treatment which mimics some of the components of a viral infection) leads to up-regulation of several chemokines, including IP-10, fractalkine, MCP-1, MIP3 $\alpha$, CINC-1 and RANTES (22). Moreover, the infection of human pancreatic islets with the coxsackie virus B5 induces the expression of the chemokines fractalkine, MIP- $2 \alpha$, MIP- $2 \beta$, GRO- $\gamma$, ENA-78, IP-10 and ITAC (23), suggesting the presence of a virus-triggered "dialogue" between beta-cells and the immune system.

Observations in several TID animal models have shown that the first immune cells to infiltrate the islets are macrophages and dendritic cells (24). These cells probably migrate to the pancreatic lymph nodes (PLNs) to recruit CD4+ T-lymphocytes, also called T-helper cells $(12,24)$. In line with this, it was shown that the removal of PLNs at 3 weeks of age protects NOD mice against the development of insulitis (12). APC first activates the naive Th0 CD4+ T-cells via presentation of beta-cell antigens on their MHC class II molecules, favoring their differentiation in Thl cells (e.g. the T-cells that enhance the cytotoxic immune response) via secre- 


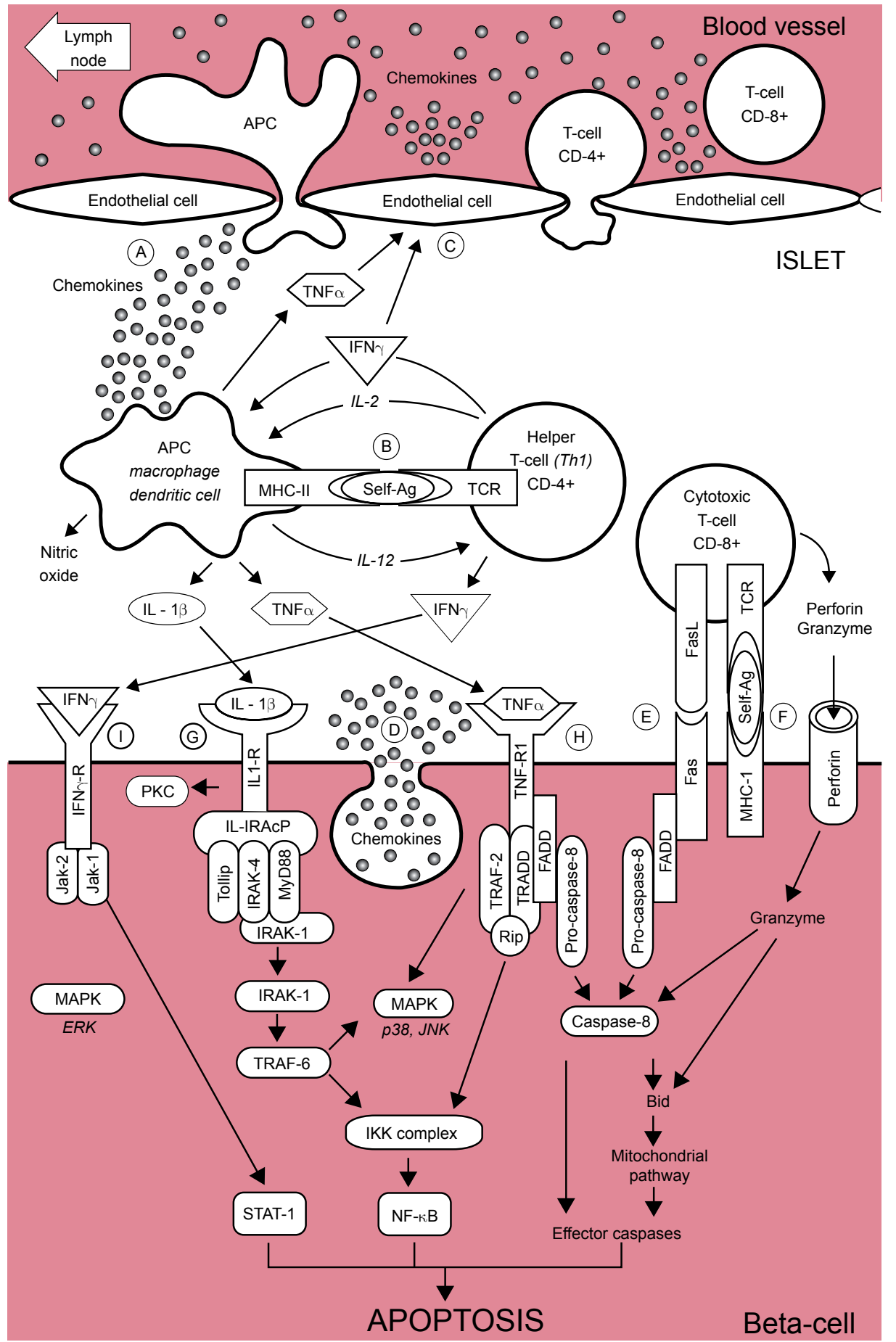

Figure 1. Schematic representation of the auto-immune attack to the beta-cells in TIDM.

(A) At the early stages of insulitis, activated local antigen presenting cells (APC) recruit and activate CD4+ helper T-cells via migration to the pancreatic lymph node, presentation of beta-cells antigens and release of chemokines/cytokines.

(B) CD4+ helper T-cells, in turn stimulate APC secretion of cytokines and nitric oxide.

(C) Cytokines induce the secretion of chemokines by endothelial cells which enhance the recruitment of immune cells into the islets and, together with cytokines, activate CD8+ cytotoxic T-cells.

(D) The beta-cell themselves also secrete chemokines in response to viral infection or cytokines, further enhancing the recruitment and activation of immune cells. Activated CD8+ cytotoxic T-cells, in turn, induce beta-cell apoptosis via

(E) the Fas pathway and

(F) the granzyme/perforin system. Cytokines also bind to receptors at the surface of beta-cells:

(G) Interleukin-1 $\beta$ (IL-1 $\beta$ ) activates NF-kB and the kinases PKC p38 and JNK.

(H) Tumor necrosis factor $\alpha$ (TNF $\alpha$ ) activates caspase-8, NF- $\mathrm{kB}$ and the MAPK p38 and JNK.

(I) Interferon $\gamma$ (IFN $\gamma$ ) activates Stat-1 and the kinase ERK. More detailled information is provided in the text. tion of interleukin-12 $(12,24)$ (Figure 1A). The differentiated Thl CD4+ T-cells, in turn, secrete IL-2 and IFN- $\gamma$ which further stimulate APC to secrete other cytokines, such as IL-1 $\beta$ and TNF- $\alpha$ and free radicals, such as nitric oxide (NO). The secreted cytokines pro- mote the migration of CD8+ cytotoxic T-cells into the islets and stimulate the beta-cells to release chemokines and IL-15 which further augment attraction and activation of immune cells $(25)$. 


\section{MEDIATORS OF BETA-CELL DESTRUCTION IN T1D}

As already discussed above, TID is a slowly-progressing autoimmune disease, and the process causing beta-cell death in humans usually evolves over several years. Clinical symptoms of diabetes are usually present once more than $70 \%$ of the beta-cell population is destroyed (26). The main form of beta-cell death observed in TID rodent models and in human islets from TID patient is apoptosis $(26,27)$. The mechanisms of beta-cell destruction in TID have not yet completely clarified, but probably involve the following: 1) Expression of Fas ligand (FasL) and its receptor Fas at the surface of the activated CD8+ T-cells and pancreatic beta-cells respectively; 2) Release of perforin and granzyme by activated CD8+ T-lymphocytes; 3 ) Secretion of cytokines, including interleukin- $1 \beta$ (IL-1 $\beta$ ), tumor necrosis factor $\alpha$ (TNF- $\alpha$ ) and interferon- $\gamma($ IFN- $\gamma$ ), by the diverse immune cells infiltrating the islet; 4) Production of reactive oxygen species such as nitric oxide (NO) by macrophages, dendritic cells and the beta-cells themselves $(24,26,27)$.

Fas, also known as APO-1 or CD95, is a member of the TNF receptor surperfamily that is activated via binding of FasL (Figure 1E) $(12,27)$. Fas and FasL were detected respectively at the surface of beta-cells and on a high percentage of T-cells infiltrating the islet (28). In addition, it was shown that Fas expression can be induced in rodent beta-cells upon stimulation with IFN- $\gamma$ and IL-1 $\beta$ (28). Once activated, Fas trimerizes and recruits the Fas-associated death domain (FADD) protein at its cytoplasmic part $(12,27)$. FADD then recruits pro-caspase- 8 leading to its activation by autocleavage. Activated caspase- 8 subsequently cleaves the effector caspase- 3 and/or activates the mitochondrial death pathway via cleavage of the $\mathrm{BH} 3$ protein Bid. The role of Fas in T-cell mediated beta-cell destruction in vivo has remained controversial for a long time, but targeted overexpression of a dominant negative form of Fas (FADD) in beta-cells delays the onset of diabetes in NOD mice, implicating a role for Fas in the early stages of autoimmune beta-cell destruction $(24,29,30)$.

Perforin and granzyme are contained in granules inside the CD8+ T-cells (12). These cytotoxic molecules are probably released in the extra-cellular milieu via exocytosis in response to TCR recognition of self-Ag presented at the surface of beta-cells by MHC class-I molecules (Figure 1F). Perforin is involved in pore for- mation across the membranes via a $\mathrm{Ca}^{2+}$ dependent mechanism. This pore enables the entry of the serine protease granzyme inside the cell, causing the cleavage and activation of several targets, such as effector caspases and the $\mathrm{BH} 3$ only protein Bid. Several studies point to the perforin/granzym system as an important mediator of T-cell-induced beta-cell death. Thus, perforin deficient RIP-LCMV mice (a virus-triggered diabetes mouse model) are protected against diabetes upon infection with lymphocytic choriomeningitis virus (LCMV), while NOD mice lacking the perforin gene develop severe insulitis but rarely became diabetic $(12,24)$.

In addition to these two CD8+ specific killing mechanisms, beta-cell death can also be induced by proinflammatory cytokines such as IL- $1 \beta$, TNF- $\alpha$ and IFN- $\gamma(26,27)$. These pro-inflamatory cytokines are detectable during early insulitis in NOD mice and $\mathrm{BB}$ rats $(24,27)$.

IL- $1 \beta$ binding to its receptor induces the formation of a multiproteic complex at its cytoplasmic domain, including the IL-1R accessory protein (IL-1RAcP), Tollip, MyD88 and two members of the serine/threonine kinase IL-1R-associated-kinase (IRAK) family, namely IRAK-1 and IRAK-4 (27) (Figure IG). IRAK-4 phosphorylates IRAK-1 causing its activation and further releases from the IL- $1 \mathrm{R}$ complex. IRAK-1 then interacts with the TNF-receptorassociated factor-6 (TRAF-6) in the cytoplasm provoking its activation by phosphorylation. TRAF-6, in turn, activates the nuclear Factor $\kappa \mathrm{B}(\mathrm{NF}-\kappa \mathrm{B})$ and/ or the mitogen activated protein (MAPK) pathway. TRAF- 6 activates the IKB kinase (IKK) complex via an ubiquitinilation-mediated mechanism which is not yet clearly understood. IKK then phosphorylates the inhibitors of NF- $\kappa \mathrm{B}, \mathrm{I} \kappa \mathrm{Bs}$, causing their degradation. This last event frees NF- $\kappa \mathrm{B}$ and enables its translocation into the nucleus, where it regulates the transcription of several target genes. Depending on the cell type and the inducing stimuli, NF- $\mathrm{\kappa B}$ mediates anti- or pro-apoptotic effects (31). Overexpression of an NF- $\mathrm{BB}$ super-repressor using viral vector protects rodent pancreatic beta-cells against cytokine-induced apoptosis (26) and transgenic mice expressing an NF- $\kappa \mathrm{B}$ super-repressor are resistant against experimental diabetes induced by multiple low-doses streptozotocin (32). It has been shown in rat insulinoma cells that IL-1 $\beta$ preferentially induces the phosphorylation and activation of p38 and JNK (33). IL-1 $\beta$ also activates Protein Kinase C $\delta$ 
(PKC8) via an IRAK-independent mechanism which might involve the up-regulation of phospholypase D-1 (27). Evidence for the role of IL- $1 \beta$ in in vivo beta-cell killing was provided in IL- $1 \mathrm{R}$ deficient NOD mice, which present a delayed onset of diabetes (34). Moreover, blocking IL-1 signaling with an IL-1 receptor antagonist delays the onset of diabetes in NOD mice, prevents the induction of diabetes by multiple low doses of streptozotocin, prolongs mouse islet allograft survival and prevents the recurrence of hyperglycemia in diabetic NOD mice following islet transplantation (27). Besides its pro-apoptotic effects, IL-1 $\beta$ also affects beta-cell function. Thus, IL-1 $\beta$ induces an early release of insulin followed by a progressive inhibition of glucose-stimulated insulin secretion in rodent beta-cells (35). This latest effect of IL- $1 \beta$ is due to a decrease in glucose metabolism and a reduction in the number of insulin granules docked to the plasma membrane $(35,36)$. In human beta-cells IL- $1 \beta$, in combination with IFN- $\gamma$, impairs conversion of pro-insulin into mature insulin and, after 3-7 days, triggers beta-cell apoptosis $(37,38)$.

The activation of the TNF receptor $\mathrm{l}$ (TNF-Rl) upon TNF- $\alpha$ binding leads to its trimerization and recruitment of the adaptator protein TNF receptor-associated death domain protein (TRADD) (27) (Figure $1 H)$. TRADD, in turn, recruits TRAF-2 and the serine threonine kinase Rip. Similar to TRAF-6, TRAF-2 activates both the NF- $\kappa B$ and MAPK pathways. TRAF-2 acts in cooperation with Rip to induce NF- $\mathrm{BB}$ via activation of the IKK complex. TRAF-2 probably activates the MAPK pathway in a similar way as TRAF- 6 , since it interacts with the MAP3Ks Ask-1 and MEKK-1 (27). TNF- $\alpha$ preferentially phosphorylates and activates $\mathrm{p} 38$ and JNK in rat insulinoma cells (33). In addition to TRAF-2-mediated events, the TNF-RI recruits FADD which in turn leads to pro-caspase- 8 recruitment and activation. Caspase- 8 then activates effector caspases in the same way as described above for the Fas signaling pathway (27). An important role for TNF- $\alpha$ in betacell killing was demonstrated in TNF-Rl null mutant NOD mice, which fail to develop spontaneous diabetes (24). In line with this, the development of diabetes in NOD mice by T-cell adoptive transfer is blocked by anti-TNF- $\alpha$ antibodies (39).

IFN- $\gamma$ binding to its receptor induces its oligomerization and the cytoplasmic recruitment of two members of the Janus kinase (Jak) family, Jakl and Jak2 (27) (Figure 1I). Once activated by transphosphorylation, Jakl and 2 recruit Stat- 1 and trigger its activation by phosphorylation. Stat- 1 then homodimerizes and migrates to the nucleus where it regulates the expression of genes containing $\gamma$-activated sequence (GAS) elements in their promoter, such as caspases, Fas and iNOS for instance (40). In addition to the Stat-1 pathway, the Jaks also activate a member of the MAPK family, namely the extracellular signal-regulated kinase (ERK) (27). Experiments using IFN-R null mutant NOD mice has provided discordant results, with one study showing a marked inhibition of insulitis and diabetes while the other has not detected changes in the prevalence of insulitis and diabetes $(41,42)$. Recent studies indicate that blocking Stat- 1 , the main signaling pathway of IFN- $\gamma$, prevents multiple-low dose streptozotocin-induced diabetes by an action at the beta-cell level $(43,44)$.

Cytokines act in synergy: under in vitro conditions neither TNF- $\alpha$ nor IFN- $\gamma$ alone induces beta-cell death, while IL- $1 \beta$ has a minor pro-apoptotic effect in rodent beta-cells. Beta-cell death is, however, potentiated several-fold when cytokines are used in combination $(26,27,45)$. Cytokines also synergize to induce the inducible form of nitric oxide synthase (iNOS), leading to massive NO production (27). IL-1 $\beta$ alone induces NO production in rat primary beta-cells and insulinoma cells (INS-1E) and this effect is augmented by IFN- $\gamma$ or TNF- $\alpha(27,46)$. Combinations of cytokines (i.e. IL-1 $\beta+$ IFN- $\gamma$ or TNF- $\alpha+$ IFN- $\gamma$ ), but not any of these cytokines alone, induce iNOS expression in human islets $(27,47)$. The iNOS promoter contains two binding sites for NF- $\kappa B$, which are activated by IL- $1 \beta$ and TNF- $\alpha$, and a binding site for Stat- 1 , which is activated by IFN- $\gamma(46)$. NO is a highly reactive molecule whose effects on cell function and death are complex and vary depending on its concentration (48). High concentrations of NO provoke DNA damage, activating $\mathrm{p} 53$ which then induces poly-ADP-ribose-polymerase (PARP) (48). PARP activation may trigger cell death due to ATP depletion secondary to NAD+ consumption in the reaction of DNA repair. At high concentrations $\mathrm{NO}$ also modifies proteins via a direct chemical reaction with cysteine and tyrosine residues or heme groups, thus regulating their function (48). For instance, $\mathrm{NO}$ inhibits aconitase via interaction with its heme group, blocking the Citrate cycle and thus the production of ATP; this effect was observed in rat betacells exposed to IL-1 $\beta$ (49). NO also modulates the activity of NF- $\mathrm{KB}$ and $\mathrm{AP}-\mathrm{l}$ and interact with the zinc finger domain of other transcription factors, inhibiting 
their binding capacity (48). In line with this, nearly $50 \%$ of the cytokine-modified genes in insulin-producing cells, as observed by microarray analysis, are secondary to NO formation (50).

Of note, NO seems to have a less relevant role for cytokine-induced beta cell death in humans and mice as compared to rats. Thus, iNOS blockers do not prevent IL- $1 \beta+$ IFN- $\gamma+$ TNF- $\alpha$-induced human beta cell DNA strand breaks and death $(38,47)$, while islets obtained from an iNOS KO mouse are only partially protected against death induced by IL-1 $\beta+$ IFN- $\gamma(51)$.

\section{DOWNSTREAM MECHANISMS OF CYTOKINE-INDUCED BETA-CELL DEATH: A ROLE FOR ER STRESS?}

The downstream mechanisms involved in cytokine-induced beta-cell death still remain to be fully clarified. Available evidence suggests a role for mitochondrial mediators of apoptosis, NO, oxygen free radicals and endoplasmic reticulum (ER) stress, among others. These mechanisms have been addressed in previous reviews from our group $(26,52)$, and we will presently and briefly discuss the role for ER stress.

The endoplasmic reticulum (ER) is the organelle responsible for synthesis and folding of secreted and membranous protein and lipid biosynthesis. It also functions as one of the main cellular calcium stores. Alterations of ER homeostasis lead to accumulation of misfolded proteins and activation of an adaptive response named the unfolded protein response (UPR) $(52,53)$. The UPR is transduced via 3 ER transmembrane proteins, namely PERK, IRE-1 and ATF6. The signaling cascades activated downstream of these proteins: a) induce expression of ER resident chaperones and protein foldases, increasing the protein folding capacity of the ER; b) attenuate general protein translation which avoid overloading the stressed ER with new proteins; c) upregulate ER-associated degradation (ERAD) genes, which decreases the unfolded protein load of the ER $(52,53)$. In severe cases, failure by the UPR to solve the ER stress leads to apoptosis. The mechanisms linking ER stress to apoptosis are still poorly understood, but potential mediators include the transcription factors Chop and ATF3, pro-apoptotic members of the Bcl-2 familly, the caspase 12 and the kinase JNK (52-54).

As discussed above, cytokines contribute to betacell autoimmune destruction in TID. Cytokines, via
NO formation, induce a $50 \%$ decrease in the expression of the ER calcium pump SERCA2 pump, depleting ER $\mathrm{Ca}^{2+}$ and triggering ER stress (45). In line with this, SNAP, a chemical NO donor, increases beta-cell cytosolic $\mathrm{Ca}^{2+}$ concentrations secondary to the release of calcium from the ER depletion, while Chop knock-out islets are resistant to the toxic effects of SNAP (55). The molecular mechanisms leading to SERCA2 downregulation in response to $\mathrm{NO}$ are still unknown. NO inhibits the binding of zinc finger transcription factors (48), and the SERCA2 promoter contains a conserved binding site for the zinc finger transcription factor SP-1. SP-1 is involved in the basal expression of SER$\mathrm{CA} 2$ in cardiomyocytes and $\mathrm{C} 2 \mathrm{Cl} 2$ muscular cell line; inhibition of SPl activity by NO may thus contribute for the observed decrease in SERCA2 mRNA expression (56). Besides transcriptional regulation, $\mathrm{NO}$ also affects the function of SERCA2 at a post-transcriptional level, and nitration inhibits SERCA2 pump activity (48). IL- $1 \beta+$ IFN- $\gamma$-induced ER stress is characterized by eIF $2 \alpha$ phosphorylation and subsequent induction of ATF4, activation of Xbp- 1 alternative splicing and up-regulation of the pro-apoptotic transcription factor Chop $(45,57)$. Cytokine-induced ER stress in betacells seems to be defective for the activation of the ATF- 6 branch of the UPR, as suggested by a failure to activate an UPRE luciferase construct which responds to ATF- 6 and Xbp- 1 and lack of BiP (an ATF6 target) induction. On the other hand, free fatty acids and two chemical ER stress inducers (i.e. thapsigargin and cyclopiazonic acid) activate all three UPR pathways in betacells, including ATF6 $(45,58,59,60)$. This partial induction of ER stress, with defective up-regulation of the chaperone BiP (which may play a protective role against beta-cell death) and the effects of IFN- $\gamma$ (see below), may explain why beta-cells are particularly sensitive to cytokine-induced apoptosis.

IL- $1 \beta$ alone triggers ER stress but does not induce beta-cell death, while IFN- $\gamma$ neither causes ER stress nor induces beta-cell death. The two cytokines together, however, trigger beta-cell apoptosis. Interestingly, IFN- $\gamma$ down-regulates several ER chaperones in betacells, decreasing the ability of these cells to endure the ER stress induced by IL-1 $\beta$ (59). It is thus conceivable that the synergistic action of IL-1 $\beta$ and IFN- $\gamma$ in the induction of beta-cell apoptosis is due, at least in part, to a "double punch", namely induction of ER stress on one side and impairment of the defenses against ER stress on the other. 
Direct evidence of ER stress markers expression in beta-cells from diabetic patients is still limited. Immunostaining of islets from T2D patients (autopsy material) showed an increased expression of Chop, BiP and p58 in comparison to non-diabetic control subjects $(61,58)$. Another recent study investigated the perinuclear expression of Chop protein and its nuclear translocation in beta-cells obtained from autopsy of TID and T2D patients (62). The perinuclear expression of Chop was increased in beta-cells from T2D and obese non-diabetic patients when compared to lean non-diabetic patients. The presence of Chop in the nucleus was observed 6 times more frequently in T2D than in obese non-diabetic patients. TID samples rarely presented expression of Chop around the nucleus and the frequency of Chop positive beta-cell nuclei was comparable to the control group. The authors thus concluded that apoptosis is initiated by different mechanisms in TID and T2D and that ER stress is probably not involved in the initiation of beta-cell apoptosis in TID. The main limitation of this study is that nuclear Chop is not a specific marker of ER stress, since Chop can be induced independently of ER stress by other stress stimuli (52). Moreover, insulitis is heterogenous in the pancreas of TID patients, and another study detected ATF3 expression (similarily to Chop ATF3 is also induced downstream of ATF4) only in islets affected by insulitis (54). Specific determination of Chop expression in islets affected by insulitis was not performed in the study by Huang and co-workers (62). Additional studies are thus required to evaluate the involvement of ER stress in human TID pathogenesis.

The evidence described in the present review, and in the other articles of this issue, indicates that our knowledge of the pathogenesis of TID has greatly increased in recent years. Unfortunately this increased knowledge has not yet been translated into safe and innovative therapies to prevent the disease. Prevention of human TID will probably require interventions at multiple levels, including "re-education" of the immune system to render it tolerant to the beta-cells, stimulation of beta-cell defense/regeneration and prevention of the activation of pro-apoptotic signaling inside them. This is an enormous task, which will require concerted and long-term efforts by basic and clinical researchers. For this purpose, it is imperative that we redouble our efforts to better understand the mechanisms of betacell death in diabetes and, based on this knowledge, succeed in designing rational and targeted therapies to prevent beta-cell loss.

\section{ACKNOWLEDGEMENTS}

We apologize for not quoting many relevant original papers due to space limitations in the reference list, we quoted preferentially review articles. Work by the authors mentioned in the article was supported by grants from the European Union (STREP Savebeta, contract $n^{\circ}$ 036903; in the Framework Programme 6 of the European Community), the Fonds National de la Recherche Scientifique (FNRS), Actions de Recherche Concertées de la Communauté Française, Belgium, the Belgium Program on Interuniversity Poles of Attraction initiated by the Belgian State (IUAP P5/17 and P6/40) and the Juvenile Diabetes Foundation International (JDRF). Alessandra K. Cardozo is presently a Research Associate of the Fonds National de la Recherche Scientifique (FNRS; Belgium).

\section{REFERENCES}

1. Daneman D. Type 1 diabetes. Lancet. 2006;367:847-58.

2. Jahromi MM, Eisenbarth GS. Cellular and molecular pathogenesis of type 1A diabetes. Cell Mol Life Sci. 2007;64:865-72.

3. Kim MS, Polychronakos C. Immunogenetics of type 1 diabetes. Horm Res. 2005;64:180-8.

4. Todd JA, Walker NM, Cooper JD, Smyth DJ, Downes K, Plagnol $V$ et al. Robust associations of four new chromosome regions from genome-wide analyses of type 1 diabetes. Nat Genet. 2007;447:661-78

5. The Wellcome Trust Case Control Consortium. Genome-wide association study of 14,000 cases of seven common diseases and 3,000 shared controls. Nature. 2007;447:661-78.

6. Turner D. The human leucocyte antigen (HLA) system. Vox Sang. 2004;87(Suppl1):87-90.

7. Wong FS,Wen L. What can the HLA transgenic mouse tell us about autoimmune diabetes? Diabetologia. 2004;47:1476-87.

8. Pihoker C, Gilliam LK, Hampe CS, Lernmark A. Autoantibodies in diabetes. Diabetes. 2005;54:S52-61.

9. Wenzlau JM, Juhl K, Yu L, Moua O, Sarkar SA, Gottlieb P et al. The cation efflux transporter ZnT8 (SIc30A8) is a major autoantigen in human type 1 diabetes. Proc Natl Acad Sci USA. 2007;104:17040-5.

10. In't Veld P, Lievens D, De Grijse J, Ling Z, Van der Auwera B, Pipeleers-Marichal $M$ et al. Screening for insulitis in adult autoantibody-positive organ donors. Diabetes. 2007;56:2400-4.

11. Knip M, Veijola R, Virtanen SM, Hyoty $H$, Vaarala $O$, Akerblom HK. Environmental triggers and determinants of type 1 diabetes. Diabetes. 2005;54(Suppl2):S125-36.

12. Pearl-Yafe M, Kaminitz A, Yolcu ES, Yaniv I, Stein J, Askenasy N. Pancreatic islets under attack: cellular and molecular effectors. Curr Pharm Des. 2007;13:749-60.

13. van der Werf N, Kroese FG, Rozing J, Hillebrands JL. Viral infections as potential triggers of type 1 diabetes. Diabetes Metab Res Rev. 2007;23:169-83.

14. Dotta F, Censini S, van Halteren AG, Marselli L, Masini M, Dionisi $S$ et al. Coxsackie B4 virus infection of beta cells and natu- 
ral killer cell insulitis in recent-onset type 1 diabetic patients. Proc Natl Acad Sci USA. 2007;104:5115-20.

15. Imagawa A, Hanafusa T, Tamura S, Moriwaki M, Itoh N, Yamamoto $\mathrm{K}$ et al. Pancreatic biopsy as a procedure for detecting in situ autoimmune phenomena in type 1 diabetes: close correlation between serological markers and histological evidence of cellular autoimmunity. Diabetes. 2001;50:1269-73.

16. Uno S, Imagawa A, Okita K, Sayama K, Moriwaki M, Iwahashi $\mathrm{H}$ et al. Macrophages and dendritic cells infiltrating islets with or without beta-cells produce tumour necrosis factor-alpha in patients with recent-onset type 1 diabetes. Diabetologia. 2007;50:596-601.

17. Yang Y, Santamaria P. Lessons on autoimmune diabetes from animal models. Clin Sci (Lond). 2006;110:627-39.

18. Lenzen S, Tiedge M, Elsner M, Lortz $S$, Weiss $H$, Jorns $A$ et al. The LEW.1AR1/Ztm-iddm rat: a new model of spontaneous insulin-dependent diabetes mellitus. Diabetologia. 2001;44:1189-96.

19. Rotondi M, Chiovato L, Romagnani S, Serio M, Romagnani P. Role of chemokines in endocrine autoimmune diseases. Endocr Rev. 2007;28:492-520

20. Grewal IS, Rutledge BJ, Fiorillo JA, Gu L, Gladue RP, Flavell RA et al. Transgenic monocyte chemoattractant protein-1 (MCP-1) in pancreatic islets produces monocyte-rich insulitis without diabetes: abrogation by a second transgene expressing systemic MCP-1. J Immunol. 1997;159:401-8.

21. Cameron MJ, Arreaza GA, Grattan M, Meagher C, Sharif $S$, Burdick MD et al. Differential expression of CC chemokines and the CCR5 receptor in the pancreas is associated with progression to type I diabetes. J Immunol. 2000;165:1102-10.

22. Liu D, Cardozo AK, Darville MI, Eizirik DL. Double-stranded RNA cooperates with interferon-gamma and IL-1 beta to induce both chemokine expression and nuclear factor-kappa Bdependent apoptosis in pancreatic beta-cells: potential mechanisms for viral-induced insulitis and beta-cell death in type 1 diabetes mellitus. Endocrinology. 2002;143:1225-34.

23. Ylipaasto P, Kutlu B, Rasilainen S, Rasschaert J, Salmela K, Teerijoki $\mathrm{H}$ et al. Global profiling of coxsackievirus- and cytokine-induced gene expression in human pancreatic islets. Diabetologia. 2005;48:1510-22.

24. Yoon JW, Jun HS. Autoimmune destruction of pancreatic beta-cells. Am J Ther. 2005;12:580-91.

25. Cardozo AK, Proost P, Gysemans C, Chen MC, Mathieu C, Eizirik DL. IL-1beta and IFN-gamma induce the expression of diverse chemokines and IL-15 in human and rat pancreatic islet cells, and in islets from pre-diabetic NOD mice. Diabetologia. $2003 ; 46: 255-66$.

26. Cnop M, Welsh N, Jonas JC, Jorns A, Lenzen S, Eizirik DL. Mechanisms of pancreatic beta-cell death in type 1 and type 2 diabetes: many differences, few similarities. Diabetes. 2005;54(Suppl 2):S97-107.

27. Eizirik DL, Mandrup-Poulsen T. A choice of death - the signaltransduction of immune-mediated beta-cell apoptosis. Diabetologia. 2001;44:2115-33.

28. Kawasaki E, Abiru N, Eguchi K. Prevention of type 1 diabetes: from the view point of beta-cell damage. Diabetes Res Clin Pract. 2004;66(Suppl 1):S27-32.

29. Allison J, Thomas HE, Catterall T, Kay TW, Strasser A. Transgenic expression of dominant-negative Fas-associated death domain protein in beta-cells protects against Fas ligand-induced apoptosis and reduces spontaneous diabetes in non-obese diabetic mice. J Immunol. 2005;175:293-301.
30. Savinov AY, Tcherepanov A, Green EA, Flavell RA, Chervonsky AV. Contribution of Fas to diabetes development. Proc Natl Acad Sci USA. 2003;100:628-32.

31. Ortis F, Cardozo AK, Crispim D, Storling J, Mandrup-Poulsen T, Eizirik DL. Cytokine-induced proapoptotic gene expression in insulin-producing cells is related to rapid, sustained, and nonoscillatory nuclear factor-kappaB activation. Mol Endocrinol. 2006;20:1867-79.

32. Eldor R, Yeffet A, Baum K, Doviner V, Amar D, Ben-Neriah $Y$ et al. Conditional and specific NF-kappaB blockade protects pancreatic beta-cells from diabetogenic agents. Proc Natl Acad Sci USA. 2006;103:5072-7.

33. Saldeen J, Lee JC, Welsh N. Role of p38 mitogen-activated protein kinase ( $\mathrm{p} 38 \mathrm{MAPK}$ ) in cytokine-induced rat islet cell apoptosis. Biochem Pharmacol. 2001;61:1561-9.

34. Thomas HE, Irawaty W, Darwiche R, Brodnicki TC, Santamaria $\mathrm{P}$, Allison $\mathrm{J}$ et al. IL-1 receptor deficiency slows progression to diabetes in the NOD mouse. Diabetes. 2004;53:113-21.

35. Sandler S, Eizirik DL, Svensson C, Strandell E, Welsh M, Welsh $\mathrm{N}$. Biochemical and molecular actions of interleukin-1 on pancreatic beta-cells. Autoimmunity. 1991;10:241-53.

36. Ohara-Imaizumi M, Cardozo AK, Kikuta T, Eizirik DL, Nagamatsu S. The cytokine interleukin-1beta reduces the docking and fusion of insulin granules in pancreatic beta-cells, preferentially decreasing the first phase of exocytosis. J Biol Chem. 2004;279:41271-4.

37. Hostens K, Pavlovic D, Zambre Y, Ling Z, Van Schravendijk C, Eizirik DL et al. Exposure of human islets to cytokines can result in disproportionately elevated proinsulin release. J Clin Invest. 1999;104:67-72.

38. Delaney CA, Pavlovic D, Hoorens A, Pipeleers DG, Eizirik DL. Cytokines induce deoxyribonucleic acid strand breaks and apoptosis in human pancreatic islet cells. Endocrinology. 1997; 138:2610-4.

39. Suk K, Kim S, Kim YH, Kim KA, Chang I, Yagita H et al. IFN-gam$\mathrm{ma} / \mathrm{TNF}$-alpha synergism as the final effector in autoimmune diabetes: a key role for STAT1/IFN regulatory factor-1 pathway in pancreatic beta-cell death. J Immunol. 2001;166:4481-9.

40. Battle TE, Frank DA. The role of STATs in apoptosis. Curr Mol Med. 2002;2:381-92.

41. Wang B, Andre I, Gonzalez A, Katz JD, Aguet M, Benoist $C$ et al. Interferon-gamma impacts at multiple points during the progression of autoimmune diabetes. Proc Natl Acad Sci USA. 1997;94:13844-9.

42. Thomas HE, Parker JL, Schreiber RD, Kay TW. IFN-gamma action on pancreatic beta-cells causes class I MHC upregulation but not diabetes. J Clin Invest. 1998;102:1249-57.

43. Gysemans CA, Ladriere L, Callewaert H, Rasschaert J, Flamez $D$, Levy DE et al. Disruption of the gamma-interferon signaling pathway at the level of signal transducer and activator of transcription-1 prevents immune destruction of beta-cells. Diabetes. 2005;54:2396-403.

44. Callewaert HI, Gysemans CA, Ladriere L, D'Hertog W, Hagenbrock J, Overbergh L et al. Deletion of STAT-1 pancreatic islets protects against streptozotocin-induced diabetes and early graft failure but not against late rejection. Diabetes. 2007;56:2169-73.

45. Cardozo AK, Ortis F, Storling J, Feng YM, Rasschaert J, Tonnesen $M$ et al. Cytokines downregulate the sarcoendoplasmic reticulum pump $\mathrm{Ca}^{2+}$ ATPase $2 \mathrm{~b}$ and deplete endoplasmic reticulum $\mathrm{Ca}^{2+}$, leading to induction of endoplasmic reticulum stress in pancreatic beta-cells. Diabetes. 2005;54:452-61. 
46. Darville MI, Eizirik DL. Regulation by cytokines of the inducible nitric oxide synthase promoter in insulin-producing cells. Diabetologia. 1998;41:1101-8.

47. Eizirik DL, Sandler S, Welsh N, Cetkovic-Cvrlje M, Nieman A, Geller DA et al. Cytokines suppress human islet function irrespective of their effects on nitric oxide generation. J Clin Invest. 1994;93:1968-74.

48. Pacher P, Beckman JS, Liaudet L. Nitric oxide and peroxynitrite in health and disease. Physiol Rev. 2007;87:315-424.

49. Welsh N, Eizirik DL, Bendtzen K, Sandler S. Interleukin-1 beta-induced nitric oxide production in isolated rat pancreatic islets requires gene transcription and may lead to inhibition of the Krebs cycle enzyme aconitase. Endocrinology. 1991;129:3167-73.

50. Kutlu B, Cardozo AK, Darville MI, Kruhoffer M, Magnusson N, Orntoft $T$ et al. Discovery of gene networks regulating cytokine-induced dysfunction and apoptosis in insulin-producing INS-1 cells. Diabetes. 2003;52:2701-19.

51. Liu D, Pavlovic D, Chen MC, Flodstrom M, Sandler S, Eizirik DL. Cytokines induce apoptosis in beta-cells isolated from mice lacking the inducible isoform of nitric oxide synthase (iNOS-/-). Diabetes. 2000;49:1116-22.

52. Eizirik DL, Cardozo AK, Cnop M. The role for endoplasmic reticulum stress in diabetes mellitus. Endocr Rev. 2008;in press:

53. Ron D, Walter P. Signal integration in the endoplasmic reticulum unfolded protein response. Nat Rev Mol Cell Biol. 2007:8:519-29.

54. Hartman MG, Lu D, Kim ML, Kociba GJ, Shukri T, Buteau J et al. Role for activating transcription factor 3 in stress-induced beta-cell apoptosis. Mol Cell Biol. 2004;24:5721-32.

55. Oyadomari S, Takeda K, Takiguchi M, Gotoh T, Matsumoto M, Wada l et al. Nitric oxide-induced apoptosis in pancreatic betacells is mediated by the endoplasmic reticulum stress pathway. Proc Natl Acad Sci USA. 2001;98:10845-50.

56. Wankerl M, Boheler KR, Fiszman MY, Schwartz K. Molecular cloning and analysis of the human cardiac sarco(endo)plasmic reticulum $\mathrm{Ca}^{2+}$-ATPase (SERCA2) gene promoter. J Mol Cell Cardiol. 1996;28:2139-50.
57. Pirot $\mathrm{P}$, Ortis F, Cnop M, Ma Y, Hendershot LM, Eizirik DL et al. Transcriptional regulation of the endoplasmic reticulum stress gene chop in pancreatic insulin-producing cells. Diabetes. 2007;56:1069-77.

58. Laybutt DR, Preston AM, Akerfeldt MC, Kench JG, Busch AK, Biankin AV et al. Endoplasmic reticulum stress contributes to beta-cell apoptosis in type 2 diabetes. Diabetologia. 2007; 50:752-63.

59. Pirot $P$, Eizirik DL, Cardozo AK. Interferon-gamma potentiates endoplasmic reticulum stress-induced death by reducing pancreatic beta-cell defence mechanisms. Diabetologia. 2006;49: 1229-36.

60. Kharroubi I, Ladriere L, Cardozo AK, Dogusan Z, Cnop M, Eizirik DL. Free fatty acids and cytokines induce pancreatic beta-cell apoptosis by different mechanisms: role of nuclear factor-kappaB and endoplasmic reticulum stress. Endocrinology. 2004; 145:5087-96.

61. Cnop M, Ladriere L, Hekerman P, Ortis F, Cardozo AK, Dogusan $Z$ et al. Selective inhibition of eukaryotic translation initiation factor 2 alpha dephosphorylation potentiates fatty acid-induced endoplasmic reticulum stress and causes pancreatic beta-cell dysfunction and apoptosis. J Biol Chem. 2007;282:3989-97.

62. Huang CJ, Lin CY, Haataja L, Gurlo T, Butler AE, Rizza RA et al. High Expression Rates of Human Islet Amyloid Polypeptide Induce Endoplasmic Reticulum Stress-Mediated Beta-Cell Apoptosis, a Characteristic of Humans with Type 2 but Not Type 1 Diabetes. Diabetes. 2007;56:2016-27

Address for correspondence:

Décio L. Eizirik

Laboratory of Experimental Medicine, Université Libre de Bruxelles

Route de Lennik, 808 - CP-618, 1070 - Brussels - Belgium

E-mail: deizirik@ulb.ac.be 